\title{
THE INFLUENCE OF RESTAURANT ATTRIBUTES ON MUSLIM CONSUMERS TOWARDS SUBSCRIBING HALAL RESTAURANT IN COMPARISON STUDY: BOGOR AND KOTA KINABALU
}

\author{
Andika Nuraga Budiman ${ }^{*}$, Hilma Suyana ${ }^{2}$ \\ ${ }^{1,2}$ University of YARSI, Indonesia \\ * Corresponding author; Email: Andika.nuraga@yarsi.ac.id
}

\begin{abstract}
Halal certification does not only mean not only the food served halal but also the entire process must be halal as well. Therefore, Halal certification is important in the aspect of Indonesian and Malaysian food industry especially in the Halal Restaurant. This study objective is to understand the influence of Restaurant's attribute Restaurant and extrinsic on consumer's attitude and subscribing of the Halal Restaurant from Malaysian and Indonesian consumers. In addition, this study expecting the result comparison between Bogor and Kota Kinabalu respondent. This study used 200 respondents in total; each city received half of the targeted number of respondents. This study used quantitative method to reach respondents; they are Muslims who wanted to consume Halal food and beverages. The result shows that, among Muslims, we found the different perception towards subscribing Halal Restaurant, we considered that Bogor respondents only give attention in restaurant service quality attributes when they are subscribing Halal Restaurant Meanwhile, this study found that Kota Kinabalu respondents are very consider about quality, value, and risk. The point of this result is even they are same religion; they still have different perspective and perception.
\end{abstract}

Keywords: Halal, Perception Restaurant.

\begin{abstract}
Abstrak: Sertifikasi halal tidak hanya berarti tidak hanya makanan yang disajikan halal tetapi juga seluruh proses harus halal juga. Oleh karena itu, sertifikasi halal penting dalam aspek industri makanan Indonesia dan Malaysia terutama di Restoran Halal. Tujuan penelitian ini adalah untuk memahami pengaruh atribut Restaurant Restaurant dan ekstrinsik pada sikap konsumen dan berlangganan Restoran Halal dari konsumen Malaysia dan Indonesia. Selain itu, penelitian ini mengharapkan perbandingan hasil antara responden Bogor dan Kota Kinabalu. Penelitian ini menggunakan 200 responden secara total; setiap kota menerima setengah dari jumlah responden yang ditargetkan. Penelitian ini menggunakan metode kuantitatif untuk menjangkau responden; Mereka adalah muslim yang ingin mengkonsumsi makanan dan minuman halal. Hasilnya menunjukkan bahwa, di kalangan umat Islam, kami menemukan persepsi yang berbeda terhadap berlangganan Halal Restaurant, kami menganggap bahwa responden Bogor hanya memberikan perhatian pada atribut kualitas layanan Restoran ketika mereka berlangganan Halal Restaurant Sementara itu, penelitian ini menemukan bahwa responden Kota Kinabalu sangat mempertimbangkan kualitas, nilai, dan risiko. Inti dari hasil ini adalah bahkan mereka adalah agama yang sama; Mereka masih memiliki perspektif dan persepsi yang berbeda.
\end{abstract}

Kata kunci: Halal, Persepsi Restoran.

\section{INTRODUCTION}

Muslim's life revolves around the concept of halal and haram. Halal is more relative to food and drink, and means 'allowed to be consumed by Muslims'. Haram is the opposite; this can see from the suspicion that observed. Masbooh is referring to the origin of an unknown object in which there is uncertainty about its status in Islam. Fundamentally, all food products are permitted, except explicitly prohibited in the Quran (Chapter II, Verse 168) such as alcohol, pigs, blood, meat from carcasses, and animal flesh that have not slaughtered according to Islamic rules (Bonne \& Verbeke, 2008). Islam also emphasizes the importance of establishing toyyib rules, which means a nutritious, high quality, and safe food.

The core definition of Halal is based on Islamic principles in which he says that everything is lawful according to his nature "He has also submitted to you all that is in heaven and on earth" (Holy Qur'an, Sura Aljāthiyah: 13). Non-Halal or Haram has been specified as an exception, and the main exceptions of Halal are: ethanol (alcohol) (Alzeer \& Abou Hadeed, 2016), blood, pigs, carnivores and omnivorous animals, food contaminated with non-kosher ingredients and food with toxic potential materials that can harm human health. Indeed, Islam emphasis on food safety issues, so it is often linking the concept of Halal by Halal Tayyib when associated with food "Oye who believe! Eat clean and pure that we have prepared for you, and be give thanks to Allah, if that is you whom you worship "(Holy Quran, Sūrat Albaqarah: 172).

Food is a fundamental resource in our daily lives, it contains nutrients, such as proteins, carbohydrates, fats, minerals and vitamins, to provide energy to live and thrive. The food industry today offers us with a 
variety of colours with quality food that has measured by standard products from the food industry. Food is a fundamental resource in our daily lives, it contains nutrients, such as proteins, carbohydrates, fats, minerals and vitamins, to provide energy to live and thrive. The food industry today offers us with a variety of colours with quality food that has directed by standard products from the food industry. Most importantly, food can also have the potential for disease transmission, so the quality of food plays an important role to maintain human health. Food safety very important in sustaining life and safeguarding public health. Especially, by way of safe handling, preparation and storage of food helps prevent disease (Chaves, Alvarenga, Campagnollo, Caltura, \& SantAna.)

The opposite of halal is haram and very important for industry players in the Restaurant sector avoid offering food and drinks are prohibited such as pork and alcohol to be served in their dining area. In to follow the lawful demands, the entire supply chain must follow the standard kosher food including slaughtering, storage, display and preparation. Thus, the standard makes it mandatory requirement to separate physically from the halal food and products forbidden.

Malaysian Standard MS 1500 Guidance on Production, Preparation, Handling and Storage of Halal Food set of practical guidelines for the food industry about the suitability kosher. In addition, the Hazard Analysis Critical Control Point (HACCP) and halal system will work together ensure that the product is safe and can be consumed by anyone, including nonMuslims. In Malaysia's various regulatory standards set the context for the Restaurant to be sure that to be halal compliant they must be able to explain all aspects of the food from the farm to the plate: the segments from the source of raw materials, handling, processing equipment, tools processing, storage, transport, prepare and send to the customer. The MS1500:2019 for an example, it is every requirements and inclusion clauses is adopted by JAKIM, a Halal regulatory body in Malaysia as part of the provision in Halal certification. JAKIM uses the standards as primary references for Halal certification, supported by specifically developed guidelines and manual procedures. Halal certification applicants must achieve compliances to every requirement in the standards. For this, JAKIM needs to conduct a compliance audit to verify the conformance, before granting the Halal certification. Non-compliances to this requirement in the standards will result in a penalty (Ahmad, 2019).

Indonesia, which according to the Global Islamic Economy Indicator 2017 is the country in the first rank of shopping for halal food products and ranked sixth in the world for drug and cosmetics spending (Nasar, 2017), regulates the procedures for halal certification through a special non-governmental organization called the Indonesian Ulema Council (MUI) which led by LPPOM MUI. Even though the level of public awareness and awareness of halal products has reached 92.2\% (Sasongko and Puji, 2011), only 37\% of all products sold in Indonesia have halal certificates. The Head of LPPOM MUI added that out of 113 thousand products registered in Indonesia; only 41 thousand products labelled halal. The number of products that still do not have a halal label may be due to the voluntary principles adhered to by the halal certifycation system in Indonesia (Abdul et al., 2013). According to Hakim (2015), other possible causes are due to uncertainty and the absence of specific rules regarding halal product guarantees as the basic standard issued by the government.

On the contrary, the rules about it are scattered in a number of regulations that mainly address certain other subjects. Viverita, Kusumastu sti and Rachmawati (2017) in their study said that the reason for the lack of interest in applying for halal certification is that the cost standard set by LPPOM MUI varies from 2.8 million rupiah to 3.7 million rupiah, which is relatively too expensive for small businesses, medium, or newly formed. Because Small and Medium Enterprises (UKM) are under the responsibility of the Ministry of Cooperatives and SMEs, LPPOM MUI is not obliged to directly support SMEs to obtain halal certificates.

\section{Problem Identification}

Halal certification does not only mean not only the food served halal but also the entire process must be halal as well. Therefore, Halal certification is important in the aspect of Malaysian food industry especially in the halal Restaurant (Marzuki, 2014). Meanwhile, Malaysian consumers are becoming more conscious of Halal (Shafie and Othman, 2004). In Malaysia, there were concerns on the use of invalid and invalid forms of Halal certificate (Zakaria, 2008; Talib et. al. 2008; Shafie and Othman, 2006). Abdul (2006) investigated how the Moslem consumer in Malaysia purchase Halal food to Subscribing of Halal Restaurant. They found that Moslem consumers looking for a guarantee indicatory the place of business is Halal, Halal food and that the Halal logo conveyed and convince customers that the food is fit for the consumption for a Moslem. In line with owing to the multicultural of Malaysia, not all of local Restaurant is systematically Halal and with a new image known as pork free Restaurant rapidly appeared especially in Kuala Lumpur and Selangor and other states as well. Pork-free Restaurant become new marketing strategies 
in Islamic Marketing. (Safie and Othman, 2006). The study of Haroun, ET. al.(2014) found that there are three (3) categories of pork free Restaurant s, 1) the Restaurant pork free that served non-alcohol beverages and received Halal certification from JAKIM, 2) pork free Restaurant but the owner of the Restaurant wish the non-Moslem customers and therefore alcohol is served which as a result to Restaurant will not receive Halal certification from JAKIM even though the Restaurant does not serve pork, 3) the Restaurant which served non-pork or called Halal food Restaurant but operated by non-Moslem workers and without having Halal certification from JAKIM. In his findings, many of Restaurant owners highlighted the type of pork free Restaurant as Halal Restaurant, because the perception of non-Moslems has a thought that pork free food is Halal food, therefore, they serve pork free foods and beverages as Halal products, but in the fact Halal process is not only about free from pork ingredients (Haroun et. al. 2014).

In Indonesia, there is a Research Institute for Food Drugs and Cosmetics-Indonesian Ulema Council (LPPOM-MUI). A study institution established by the MUI (Indonesian Ulema Council) to run an MUI functionality protecting Moslem consumers in consuming the Halal food products, drugs, and cosmetics. Study of Adiningsih (2012) found that Restaurant business is one of the prospective business in Indonesia. However, many people have to eat and the opportunities to grow in line with the market in Indonesia with the introduction of variety of Restaurant $s$ in Jakarta is in Indonesia. With the concerns regarding the food safety, the needs of consumers become to the need of more convenience and modern facilities of Indonesia in the food sector (Dyck et. al. 2011). The factor, which has found by Fitriantini (2014) that cause of hotel and Restaurant owners do not take care of MUI (Majelis Ulama Indonesia) certification and attempted to resolve the issue. In the study of Fitriantini (2014), from 803 Restaurant s only 6 Restaurant s which have Halal certification and one Restaurant not extending the Halal certification. Fitriantini (2014) argued that factors that lead to this problem is the high payment, process of management is complicated, only healthy department investigated, and low socialize from MUI, MUI plays very important for giving the certification of Halal especially for hotel and Restaurant. It is still difficult to convince if the chef in a Restaurant is Moslem using a Halal raw material then the food said as Halal food (Fitriantini, 2014). However, Indonesian consumers still prefer to Subscribing Restaurant in Indonesia regardless if it is Halal or non-Halal. Thus, from these previous issues above, this is interesting for this study to investigate comparison of Muslim perception towards subscribing Halal Restaurant in comparison study among Bogor and Kota Kinabalu respondents.

\section{LITERATURE REVIEWS}

Previous studies indicated that Restaurant and extrinsic Restaurant attributes have a significant relationship with consumer's attitude and subscribing the Restaurant. One of the studies has been done is the study of Monteiro (2000) studied the determinant factors that influence of Restaurant and extrinsic attributes towards the Subscribing of Indian Restaurant $\mathrm{s}$ and Hussain (2011), his research studied the analyses effect of extrinsic product cues (store name, brand name, price) and customer service on Restaurant image to build Subscribing behaviour. From these studies above, there are significant relationship between Restaurant and extrinsic attributes toward subscribing behaviour. Such as the process of consumer's attitude to makes decision-making is under the scanner in order to understand how people selected Restaurant $\mathrm{s}$, weigh attributes in Restaurant selections, attributes that influenced of menu selection (Upadhyay, et. al. 2007). In addition, the consumer's attitude and evaluations of products based on Restaurant cues and extrinsic cues with increasingly important when Restaurant cues are difficult to assess. However, the study of Espejel, et. al. (2007) suggested that Restaurant and extrinsic attributes are very important to influence consumer's perception.

\section{Perceived Quality}

The importance of maintaining quality of service to maintain market, According to Parasuraman et al. (1988), service quality is define as an overall assessment similar to attitudes toward service and is generally accept as an antecedent of overall customer satisfaction. A Quality of Service has defined as an organizational ability to meet or exceed customer expectations. This is the difference between customer expectations of service and perceived service (Zeithaml et al., 1990). This can be exemplify by Comparison by customer expectations with the perception of the service delivered. If expectations are greater than performance, then perceived quality is less than satisfactory and hence customer dissatisfaction. The service literature has shown that customers are more sensitive to service variables and service quality offered by organizations (Parasuraman, Zeithaml \& Berry, 1988). There are several research contributors to Susskind and Chan (2000) products, three components that contribute to overall customer satisfaction with Restaurant s: good food, good service and pleasant 
settings. In addition, Kalra (2001) explains that dinner has become an integral part of customer lifestyle, so experienced customers have increased their expectations about quality, good service, well-cooked food and no dirty interior, while looking for value better for their money. From the above study, the perceived quality of service has an influence on consumers against subscribing intentions. Furthermore, this study will investigate the relationship between perceptions of service quality on consumer attitudes and halal Subscribing Restaurant s. In addition, previous study of Ramseook (2012) argued that high quality service is important for the success of organizations so that they can survive and strengthen their completive. In addition, the study found that there is a significant relationship between service quality and behavioural intention repressively. Since service, quality is an important factor for Restaurant s, consumer's perception and behavioural intention in Restaurant has been growl.

\section{Perceived Service Value}

In the literature, many of the concept of 'perceived value' are often poorly differentiated from other related constructs; this is because the perception of values has many meanings. Like the following example, Values can interpreted because of evaluative judgments, values referring to standards, rules, criteria, norms, goals, or ideals that serve as the basis for such evaluative assessments. 'Value' implies a 'trade-off' between benefit and sacrifice; this shows the interaction between the customer and the product or service (Payne and Holt, 2001). The Values also interpreted as an important personal belief that people hold on to themselves and the goals they strive. Because 'Values' said to implied criterion used by an individual making a preference assessment. This criterion guides people's behaviour because they reflect the desired 'ultimate existence' existence (Flint, 2004) hence the value of many different meanings and concepts (Fernandez \& Boillo, 2007). Furthermore, from the studies above there are so many variant of perceived value, in this study will be using the perceived service value as Restaurant attribute Restaurant to investigate the relationship towards Subscribing Halal Restaurant.

\section{Perceived Risk}

Risk issues, first introduced to the field of consumer behaviour research by Bauer.By identifying consumers 'perceived risks in the market and trying to explain buyers' actions, such as seeking information about products and place of purchase, brand loyalty or the interests of leaders and reference groups when buying certain goods and services (Bauer, 1964). Consumer behaviour research identified and explained some types of risks felt by consumers.
They can happen in any combination and at different levels in terms of purchasing certain goods or services. The perceived risk is a sense of uncertainty that consumers have when buying goods, cars, homes, and computers. Every time consumers consider buying a product, especially if the product is expensive (Wayne, 1999). Since the 1960s, perceived risk theory used to explain consumer's behaviour. Considerable research has examined the impact of the risk on traditional consumer decision-making (Lin, 2008). Peter and Ryan (1976) defined perceived risk as a kind of subjective expected loss, and Featherman and Pavlou (2003) also defined perceived risk as the possible loss when pursuing the desired result. Another side, Stone and Winter (1987) view risk as an expectation of loss. This understanding differs from the traditional, normative expectancy-value orientation that often views risk as "probability time's pay-off", which traces its roots to the disciplines of mathematics and economics, rather than to a psychological-driven focus for risk, which seems far more appropriate in consumer domains. Risk, involvement and trust Perceived risk also found to be related to other consumer behaviour concepts, e.g. Cognitive style (Cox, 1967). Kogan and Wallach (1964) found that self-sufficiency and independence related positively to risk taking and rigidity negatively related. Schaninger (1976) showed perceived risk and its components negatively related to self-esteem, rigidity and risk taking and positively related to anxiety measures. Hence, the perceived risk is became part of Restaurant attribute as a variable of this study for investigate perceived risk is influence to consumer's Subscribing of Halal Restaurant.

\section{Theory of Reasoned Action}

One of the research program of the most extensive and influential in the history of social psychology initiated by Martin Fishbein and theory Icek Ajzen have reasoned action (Ajzen \& Fishbein, 1980; Fishbein, 1963, 1967, 1980; Fishbein \& Ajzen, 1975; David, 2009) and the descendants of such a theory Ajzen's planned behaviours (1988, 1991). A cursory search reveals thousands of citations citation indices for each of these theories, suggesting that this research program has been very successful in terms of its influence on the field of psychology. This theory originally called Theory of Reasoned Action (TRA), developed in 1967, and then the theory continually revised and expanded by Icek Ajzen and Martin Fishbein. Starting in 1980, this theory used to study human behaviours and to develop interventions that are more striking. In 1988, something else added to the existing reasoned action model and it later named 
Theory of Planned Behaviour (TPB), to overcome the shortcomings that Ajzen and Fishbein discovered through their research using TRA. Reasoned Action Theory developed to examine the relationship between attitudes and behaviours (Fishbein and Ajzen 1975; Ajzen 1988, Werner 2004). The main concepts in Reasoned Action Theory are "principles of compatibility" and the concept of "behavioural intentions," (Fishbein and Ajzen 1975; Ajzen 1988). The principle of compatibility establishes in order to predict a particular behavior directed at a particular target in a certain context and time, specific attitudes that are in accordance with the time, target and context that must be assessed, (Fishbein and Ajzen 1975; Ajzen 1988). The concept that states the desire for behaviours that motivates individuals to engage in behaviours defined by attitudes that influence behaviours, (Fishbein and Ajzen 1975). The desire to behave shows how much effort the individual wants to commit to behaviours with a higher commitment with tendency for those behaviours carried out. The desire to behave determined by subjective attitudes and norms, (Fishbein and Ajzen 1975; Ajzen 1988).

Framework of this study is adapted by Theory of Reasoned Action (TRA) focus on behavioural believe and outcome evaluation, which is the independent variable of this study is has set to perceived service quality, perceived value, and perceived risk of Halal Restaurant. These variables has quite fundamental from previous study such as, Qin and Prybutok (2008) found that the priority of students in service quality and satisfaction is to receive sympathetic and reassuring service with comfortable operating hours. This proves that service quality is proving to be an essential element. Service quality has considered as an excellence and construct of a determinant of customer satisfaction (Gotlieb et al., 1994). Researchers (Storbacka and Lehtinen, 2001) have emphasized the relationship between service quality and customer satisfaction. For example, emerging service quality models mostly observed in the literature after the 1980s (O'Neill et al., 1998), which suggests the importance of this issue. Thus, this study provided perceived service quality as the first independent variable. Furthermore, Perceived value has studied by previous study such as, the relationship between the behaviour of the service and the quality of service perceived role and has proven its value in management/marketing (Heskett \& Sasser, 2010).

Perceived value is a psychological assessment of customers for a product or service with the expectation that product or service. Marketing researchers admire satisfaction and quality excellence, and called it a competitive advantage index organization (Birgelen,
Wetzels, and de Ruyter, 1997). Finally, the last variable perceived risk, many previous studies has studied such as, In the subject literature one may come across a statement that risk, if only perceived, becomes the main determinant of their purchasing decisions. Cox reckons that getting to know the nature and range of the risk perceived by consumer enables a better understanding of some of the aspects of consumer behaviour (Cox, 1967). Risk determines consumer-buying behaviour. Maciejewski (2011) has stated that in a situation when consumers do not see the risk in the process of purchasing certain goods or services, the fact that there is an objective risk does not affect purchasing behaviour. Means, that risk affects consumer-purchasing decisions on the conditions perceived by them. Perception of risk is a condition needed to consider risk in the category of determining the purchase decision.

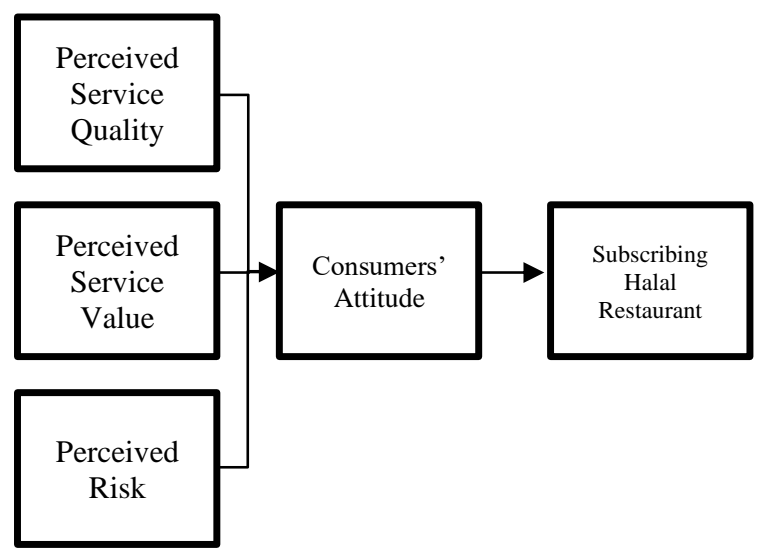

Figure 1. Framework

\section{RESEARCH DESIGN}

This research used quantitative method, which approached to 200 Muslim as respondents. These 200 respondents have divided into 100 respondents each city. Bogor has a quite influential by Halal issues, more over this is because majority populated by Muslims. Based on the Central Statistics Agency of West Java Province (BPS) in 2020, Population of Bogor has increased $0.94 \%$ from 2019. Others ethnics such as Christian, Buddhism, and Hindus followed after. This means, Muslim of Bogor dominated in Bogor. The Malaysian Census 2010 report estimates Kota Kinabalu's population at 452,058 by Malaysia's Ststistic Department. The city's current population is a mixture of many different races and ethnicities. Non-Malaysian residents form a majority of the city's population with 110,556 people followed by China $(93,429)$, Bajau/ Suluk (72,931), Kadazan-Dusun (69,993), other Bumiputras (59,107), Bruneian Melayu (35.835), Murut 2,518), India $(2,207)$ and others $(5,482)$. The Chinese are mostly Hakka and live mainly in the 
Luyang area. There is also a large Cantonese-speaking population and a small community of Hokkien and Foochow Chinese speakers scattered throughout the city. Most Foochow speakers specifically immigrated to Sabah from neighbouring Malay countries because the population is large enough Kinabalu city with a population of 452,058 numbers in the population census of 2010 in Table 2, with growth forecasts Kinabalu city will have a lot of growing population. Kota Kinabalu population in 2010 were Moslems have reached 55 percent of the total population in Kota Kinabalu. Means the number of Muslims in Kota Kinabalu has reached 254.630 Moslems (Kurniawan, 2010). Thus, this study will use Kota Kinabalu populartion of Moslem people who live in Kota Kinabalu.

This study took samples in Kota Kinabalu and Bogor. Hold the place of study in these two cities as a comparison between Muslim perceptions arises in different places and cultures. The location of this study based on Halal Problems that occurred in Malaysia and Indonesia. To take the scope of the field of study, this study takes two cities that are quite representative of the two countries. This is because the location of this sample is located in two big cities. Besides that it is also based on news about halal issues as reported from Daily Express (Published on: Wednesday, June 21, 2017), the existence of illegal chicken smuggling that occurred in Kinabalu. From the example of the news above this very interested and serious research would like to investigate really about what thought by the consumer to keep Subscribing Halal Restaurant in Kota Kinabalu. Whereas, what happened in Kota Bogor in accordance with previous research Susanto (2013) explains that some Restaurant owners in Bogor feel do not need Halal certificate to be displayed in his Restaurant? Because the sense of confident because it is already using materials that are halal, then the Restaurant owner does not feel thinking it is very important.

Some researchers indicated that samples size of 50 as very poor, 100 as poor, 300 as good, and 500 as very good, also 1000 as excellent (Comrey and Lee, 2015). Sakaran et. al. (2010) has specified three categories of non-probability sampling and the first category is much suitable for this study, which is convenience sampling. This is due to convenience sampling it is the method in getting the sample, which is on the most easily accessible members chosen as a subject. To determine appropriate sample size, this study used sample size based on the theory of Krejcie and Morgan (1970).

Questionnaire as the research instrument consist of items are relevant to measures all the variables that proposed in this study framework. Theses questionnaire will measure the proposed hypothesis. Hence, it is very important, as it will determine the whole of research and variables relationship. The questionnaire divided into two sections and contained straightforward questions. Therefore, the Subscribing of Halal Restaurant decisions within another context such as food safety, environmentally friendliness and cleanliness where these factors do play a key role. Thus, the second section contained the consumer's attitudes about Halal food consumption. Respondents asked to rank the importance of the relevant statements on their Halal food consumption decision. All items intended to measure the variables in this study were adapted from previously validated instruments. The construct of subjective norm and behavioural intention was measured with scales from Venkatesh and Davis (2000), modified so that the focus was on the Halal food purchase. Perceived behavioural control and attitude assessed with measures reported by Taylor and Todd (1995). The Items modified for Halal food purchase. Measures of attitude (four items), subjective norm (two items), perceived behavioural control (three items), and intention (five items) were measured. All questions used a six-point Likert scale in which 1 indicated "strongly disagree", 2 indicated "disagree", 3 indicated "agree", 4 indicated "strongly agree" thus, regression analysis was used to analyse the data. The design of the Likert scale has designed in four options because it is to avoid bias result.

\section{FINDINGS}

\section{Descriptive}

This part will explain the results of this study. The results shown as descriptive, reliability and hypothesis tests. The descriptive test showed from the genders, ages, marital status, and educations of respondents. The result of descriptive is consist by Indonesian (Bogor) and Malaysian (Kota Kinabalu).

Table 1 explained the different of descriptive results between Bogor and Kota Kinabalu. These results shows from the genders, woman respondents are higher compare to males. In addition, the youngsters respondent have quite numbers for giving the contribution for this study. Meanwhile, most of the respondents dominated by originality both of cities, the rest of them are outsiders. Respondent's education is quite similar, most of the respondents are undergraduate, masters, Ph.D. and others are following.

Next part, descriptive analysis of each questions of this study explained, as the result, this study has independent variables (Perceived Service Quality, Perceived Value, and Perceived Risk) and Dependent Variable (Subscribing Halal Restaurant), last, 
Consumers' Attitude as mediation variable. Each variable has minimum four questions to represent consumer's perception. Perceived service quality variable has several item in questionnaire, each item has average mean of 3 above; this study designed in Likert scale for 4 scale only (Strongly agree (4), Agree (3), Disagree (2), Strongly disagree (1)); with the mean result of perceived service quality is impressive. Next, Perceived value means also quite high in average mean of three. The perceived risk has five items which is three of item have mean in slightly answer in disagree; this is consumers respond to answer that they are not particularly feel a risk. Consumer's attitude has six items to represents Muslim perception in this study, this study found all of the means are answer agrees. These results identify the answer of both of cities.

Table 1. Descriptive results

\begin{tabular}{|c|c|c|}
\hline \multicolumn{3}{|c|}{ Bogor } \\
\hline \multirow[t]{2}{*}{ Gender } & Male & 47 \\
\hline & Female & 53 \\
\hline \multirow[t]{3}{*}{ Ages } & $19-25$ & 75 \\
\hline & $26-31$ & 14 \\
\hline & 31 above & 11 \\
\hline \multirow[t]{2}{*}{ Region } & Original & 60 \\
\hline & Outsiders & 40 \\
\hline \multirow[t]{2}{*}{ Marital Status } & Single & 10 \\
\hline & Married & 90 \\
\hline \multirow[t]{4}{*}{ Education } & Undergraduate & 74 \\
\hline & Post Graduate & 18 \\
\hline & Ph.D. & 6 \\
\hline & Others & 2 \\
\hline \multicolumn{3}{|c|}{ Kota Kinabalu } \\
\hline \multirow[t]{2}{*}{ Gender } & Male & 54 \\
\hline & Female & 46 \\
\hline \multirow[t]{3}{*}{ Ages } & $19-25$ & 89 \\
\hline & $26-31$ & 10 \\
\hline & 31 above & 1 \\
\hline \multirow[t]{2}{*}{ Region } & Original & 63 \\
\hline & Outsiders & 37 \\
\hline \multirow[t]{2}{*}{ Marital Status } & Single & 9 \\
\hline & Marired & 91 \\
\hline \multirow[t]{4}{*}{ Education } & Undergraduate & 67 \\
\hline & Post Graduate & 13 \\
\hline & Ph.D & 6 \\
\hline & Others & 4 \\
\hline
\end{tabular}

Source: Processing data with SPSS

\section{Factor Anaysis}

The previous study of Othman et. al. (2015) stated that Convergent validity of the measurement model with a reflexive indicator is assessed based on the correlation between the item score / indicator with construct score. Size reflexive said to be high if the correlation of 0.70 with the construct to measure. However, For the initial assessment phase of development of a scale measuring the loading of 0.5 until 0.6 is considered adequate Determining the input variable to a particular factor by the large correlation between variable factors, that is to the huge correlation. Result of analysis factor got from result of calculation of SPSS. With the help of SPSS has results. The next step is, the research effort is to determine whether the independent variables can be grouped into one or several factors. Again, this effort is easier to use SPSS.

Factor analysis from this study earn results from Bogor. This study found .627 of KMO and Bartlett's test result. Following the result of Eigenvalue component must more than one $(>1)$. This study found that only two factors. $46.093 \%$ variation in first factor, following $22.937 \%$ variation be able to explain in second factor. Meanwhile, Kota Kinabalu, this study found .739 of KMO and Bartlett's test. Following only one factor in $54.241 \%$ variation from total variance explained. This scree plot image can also show the number of factors formed. By looking at the component point values that have eigenvalues $>1$, it can interpreted that each city (Bogor and Kota Kinabalu) has its own number of factors.

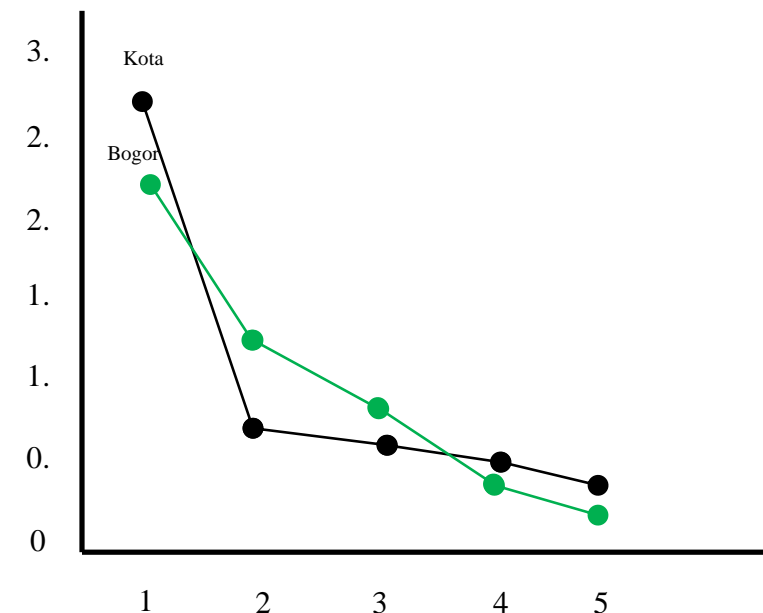

Figure 2. Scree Plot

\section{Hypothesis Test}

In this part, the investigation of hypothesis between Restaurant toward Subscribing Halal Restaurant by analysis multiple regression. The parts of Restaurant attribute are consisting to perceived service quality, perceived service value, and perceived risk. This study was using the $\mathrm{T}$ test to measure relationships between variables, This study using as a T table (1.980) for surpass by $\mathrm{T}$ value to make acceptable hypothesis.

\section{Bogor Result}

In this section will be explaining the relationship all independent variables and dependent variables through the multiple analysis regression. 
Table 2. Coefficient Restaurant towards Consumer's Attitude in Bogor

\begin{tabular}{lcl}
\hline \multicolumn{1}{c}{ Model } & t & Sig. \\
\hline Perceived Service Quality & 2.707 & .007 \\
Perceived Service Value & 1.361 & .175 \\
Perceived Risk & 1.643 & .102 \\
\hline
\end{tabular}

Source: Processing data with SPSS

From the Table 2 the result of coefficient Restaurant attribute towards consumer's attitude in Bogor. The output coefficient of perceived service quality is 0.167 in positive $(+)$ means that the more perceived service quality is increase, higher of consumer's attitude is increase in $1.67 \%$. In addition, output of coefficient perceived service value is 0.115 means that if perceived service value is increasing, then consumer's attitude is increase in $1.15 \%$. Furthermore, the output coefficient of perceived risk is 0.127 , means that if perceived risk increasing, then consumer's attitude is increase in $1.27 \%$. The hypothesis testing in this part will use the T test. The first is to find T table of this study, the $\mathrm{T}$ table of this study is 1.275 . Which mean the $\mathrm{T}$ value is must to be higher than $\mathrm{T}$ table to receive H1a for accepting hypothesis.

The acceptable hypothesis is first hypothesis (H1a) is there is a significant relationship between perceived service quality and consumer's attitude in Bogor. The first variable is perceived service quality. The $T$ value of perceived service quality is 2.707 and significant is 0.007 . Next, the second variable is perceived service value. The $\mathrm{T}$ value of perceived service value is 1.361 and significant is 0.175 was not accepted, and the last variable is perceived service risk. The $T$ value of perceived service value is 1.643 and significant is 0.102. Means, H2a and H3a rejected as well.

\section{Kota Knabalu Result}

From the Table 6 the result of coefficient Restaurant attribute towards consumer's attitude in Kota Kinabalu. The output coefficient of perceived service quality is 0.191 in positive (+) means that the more perceived service quality is increase, higher of consumer's attitude is increase in $1.91 \%$.

Table 3. Coefficient Restaurant towards Consumer's Attitude in Kota Kinabalu

\begin{tabular}{lcc}
\hline \multicolumn{1}{c}{ Model } & t & Sig. \\
\hline Perceived S. Quality & 2.605 & .010 \\
Perceived S Value & 2.273 & .024 \\
Perceived Risk & 5.886 & .000 \\
\hline
\end{tabular}

Source: Processing data with SPSS
In addition, output of coefficient perceived service value is 0.214 means that if perceived service value is increasing, then consumer's attitude is increase in $2.14 \%$. Furthermore, the output coefficient of perceived risk is 0.588 , means that if perceived risk increasing, then consumer's attitude is increase in $5.88 \%$. The hypothesis testing in this part will using the $\mathrm{T}$ test. Thus, study found all the hypothesis ( $\mathrm{H} 1 \mathrm{~b}, \mathrm{H} 2 \mathrm{~b}$, \& H3b) accepted, unlike Bogor's hypothesis results.

\section{Consumers' attitude and Subscribing Halal Restaurant}

In this section will be explaining the relationship all independent variables and dependent variables through the multiple analysis regression. This study found that there is a significant relationship between consumer's attitudes and subscribing Halal Restaurant form each cities, this study found, in Bogor, the consumers' attitude is impressively high. The Muslim Bogor is always to subscribing Halal Restaurant without a doubt.

Table 4. Coefficient Consumer's Attitude towards Subscribing Halal Restaurant

\begin{tabular}{lcc}
\hline \multicolumn{1}{c}{ Model } & t & Sig. \\
\hline Consumer's Attitude (Bogor) & 12.752 & .000 \\
Consumer's Attitude (Kota Kinabalu) & 11.805 & .000 \\
\hline
\end{tabular}

Source: Processing data with SPSS

The result of coefficient consumer's attitude towards subscribing halal Restaurant in Kota Kinabalu. The output coefficient consumer's attitude is .426 in positive $(+)$ means that the more consumer's attitude is increase, the higher of subscribing Halal Restaurant is increase by $4.26 \%$. The hypothesis testing in this part will using the $\mathrm{T}$ test. The first is to find $\mathrm{T}$ table of this study, the T table of this study is 1.275.

\section{CONCLUSION}

This study found that the comparison of hypothesis results, the first hypothesis comparison is perceived service quality; this study found that there is no significant at all in Bogor, alsop, this study found that same result in Kota Kinabalu. This mean, the respondents are significantly percept the service quality Halal Restaurant that is good. The relationship of service value, this study found the service value of Halal Restaurant was not quite affecting them to subscribing Halal Restaurant. Meanwhile, Kota Kinabalu has opposite sight of service value in Halal Restaurant, this mean Malaysian or familiar called as 
Sabahan, they have a thought about service value is important. The risk was not highly significant in Bogor, because people from Bogor tend to not carrying so much about the risk if Halal Restaurant abuses. Kota Kinabalu, has highly aware about Halalness. Because they are so much care about the important of Halalness. This does not mean, Bogor is ignorant, but they do aware the Halalness of Restaurant in other ways. The previous study by Yoo and Naeyon (2014) found that consumer's attitude mediated the relationship between antecedents of consumer attitude and consumer subscribing intention. From the result shown above, the findings indicated the there is no significant relationship between a consumer's attitude and subscribing Halal Restaurant. This mean, the consumer's attitude from combined city Kota Kinabalu and Bogor have a different result, which is indicate that the consumer's attitude is not influence by subscribing Halal Restaurant. Because even they are same Muslim, but the attitude towards subscribing Halal Restaurant is different. Otherwise, the split result for each city has different findings, the consumer's attitude has a significant relationship towards subscribing Halal Restaurant in Kota Kinabalu, which is the consumer's attitude is affecting the subscribing Halal Restaurant. Same goes for Bogor, the finding indicated that the Bogor consumer's attitude has significant relationship towards subscribing Halal Restaurant. This mean that their attitude always has to move by their instinct as a Muslim. They do not even mind about the doubtful attitude to subscribing Halal Restaurant.

\section{REFERENSES}

Abdul, M. et al. (2013) 'Indonesian Small Medium Enterprises (SMEs) and Perceptions on Halal Food Certification', African Journal Business Management, 7(16), pp. 1492-1500. doi: 10.5897/ AJBM11.2926.

Adiningsih, Kartika Puspitasari (2012), “Analisis kepuasan dan loyalitas konsumen restoran nasi bebek ginyo di Jakarta." Master's thesis, Institut Pertanian Bogor

Ajzen, I. (1988). Attitudes, personality, and behavior. Chicago: Dorsey.

Ajzen, I. (1991). The theory of planned behavior. Organizational Behavior and Human Decision Processes, 50, 179-211.

Ajzen, I., \& Fishbein, M. (1980). Understanding attitudes and predicting social behavior. Englewood Cliffs, NJ: Prentice-Hall.

Ajzen, I., \&Fishbein, M. (2005). The influence of attitudes on behavior. In D. Albarracin, B.T. Johnson, \& M.P. Zanna (Eds.), The handbook of attitudes (pp. 173-221). Mahwah, NJ: Erlbaum.
Ahmad, S. A. (2019). "Halal Related Malaysian Standards". Halal Note Series - Halal Common No. 1- 2019

Alzeer, J. \& Hadeed, K.A (2016). "Ethanol and its Halal status in food industries". November 2016Trends in Food Science \& Technology 58.

Bauer, R. A. \& Greyser, S. A. (1964) Advertising in America: The consumer view. Unpublished Graduate dissertation, Boston, MA: Harvard University

Birgelen, M., Wetzels, M., \& de Ruyter, K. (1997). Commitment in service relationships: an empirical test of its antecedents and consequences. Paper presented at the EMAC Conference Proceedings

Bonne, K., \& Verbeke, W. (2008). Religious values informing halal meat production and the control and delivery of halal credence quality. Agriculture and Human Values, 25(1), 35-47.

Comrey, A., Lee, H., 2015. A First Course in Factor Analysis, $2^{\text {nd }}$ ed. Lawrence Erlbaum Associations, Hillsdale, NJ.

Cox, D.F., Introduction" and "Risk Handling in Consumer Behaviour - an Intensive Study of Two Cases". In: Cox, Donald F., ed., Risk Taking and Information Handling in Consumer Behaviour, Boston Graduate School of Business Administration, Harvard University, Boston 1967.

Cox, D.F. (1967), "Synthesis-perceived risk and information handling", in Cox, D.F. (Ed.), Risk Taking and Information Handling on Consumer Behaviour, Harvard University Press, Boston, pp. 603-39.

David, T. (2009). "The Theory of Reasoned Action; A Case Study of Falsification in Psychology". New Mexico State University. Theory \& Psychology, Vol. 19(4): 501-518

Dyck, J., Woolverton, A. E., and Fahwani, Yuliati R. (2012). "Indonesia's Modern Food Retail Sector: Interaction with Changing Food Consumption and Trade Patterns. " United States Department of Agriculture. Issue, 9. Pp. 37.

Espejel, J., Fandos, C., and Flavian, C. (2007). "The role of Restaurant and Extrinsic Quality attributes on consumer behaviour for traditional food products. Managing Service Quality. Vol 17 (6). Pp. 681-701.

Featherman, M. and Pavlou, P. A. (2003). "Predicting e-services adoption: a perceived risk facets perspective. Int J Hun Comput Stud 2003, 59(4): 451-74

Fernandez, R.S. and Bonillo, M.A.I. (2007), "The concept of perceived value: a systematic review of the research", Marketing Theory, Vol. 7 No. 4, pp. 427-51. 
Fitriani, E. (2014). "Pelaksanaan Sertifikasi Halal di Hotel dan Restoran di Wilayah Kota Mataram dan Lombok Barat'. Science Journal. Universitas Mataram.

Flint, A. (2004). Think globally, eat locally: A new socially conscious food movement wants to reset the American table. Retrieved from chicagoconservationcorps.org

Gotlieb, J.B., Grewal, D., Brown, S.W., 1994. Consumer satisfaction and perceived quality: complementary or divergent constructs? J. Appl. Psychol. 79 (6), 875.

Hakim, A. L. (2015) 'Dissecting the Contents of Law of Indonesia on Halal Product Assurance', Indonesia Law Review, 5(1), pp. 88-103.

Haroun, M., Mohd Zahri, M., and Hemdi, M. (2014). "Pork Free Restaurant in Malaysia: Issues of Halal and Muslim Customer Patronization". @ 2014 Taylor \&Francis Group, London, ISBN 978-1-138-00151-0.

Heskett, J. L., \& Sasser, W. E. (2010). The service profit chain: from satisfaction to ownership. Handbook of Service Science, Part 1, 19-29.

Hussain, M., Ullah, H., Manzoor, S. R., and Iqbal, K. (2011)." The Effect of Extrinsic Product Cues and Customer Services/Sales Personnel on Restaurant Image, KPK, Pakistan.” International Journal of Learning and Development. Vol. 1, Issue. 1, pp. 40-58.

Kalra, R. (2001). Please please me. Restaurant Business, 100(4), 22.

Kogan, N. and Wallach, M.A. (1964), Risk-taking: A Study in Cognition and Personality, Holt, Rhinehart \& Winston, New York, NY

Kurniawan, Sutrisno. B, and Martini. D. (2014). "Responsibility Producer Concerning Giving Legal Foods Product Consumer Protection Law Perspective". Journal Penelitian UNRAM. Vol. 18 No.1, ISSN 0854-0098

Krejcie, R.V., and Morgan, D.W., "Determining sample size for research activities", Educational and Psychological Measurement, 1970, Vol. 30, pp. 607-610.

Lin W-B. (2008). "Investigation on the model of consumers' perceived risk-integrated view point. Expert Syst Appl 2008, 34(1); 977-88.

Maciejewski G. (2011), The meaning of perceived risk in purchasing decisions of the polish customers, Scientific Annals of the "Alexandru Ioan Cuza" University of Iasi, Economic Sciences, volume LVIII, edited by O. Stoica, Iasi 2011, s. 280-304. ISSN 0379-7864.

Marzuki, C. Hall, C. and Ballatine, P. (2014). "Measurement of Restaurant Manager Expectations toward Halal Certification Using Factor and Cluster Analysis". Journal of Procedia - Social and Behavioural Sciences. Vol. 121, pp 291-303.
Monteiro, P. (2000). "Factors that influence the decision of patrons to dine at selected Indian Restaurant $s$ in the Twin Cities". University of Wisconsin-Stout. pp. 1-127.

Nasar, M. F. (2017) Negara dan Sertifikasi Halal IndonesiaNegara dan Sertifikasi Halal Indonesia. Available at: https://kemenag.go.id/berita/read/ 505898/negara-dan-sertifikasi-halal-indonesia

Nunnally J, Bernstein L. (1994) "Psychometric theory." New York: McGraw-Hill Higher, INC; 1994.

O’Neill, M.A., Palmer, A.J., Beggs, R., 1998. The effects of survey timing on perceptions of service quality. Manag. Serv. Qual.: Int. J. 8(2), 126-132.

Parasuraman, A., Zeithaml, V. A, and Berry, L.L. (1988). "SERVQUAL: A Multiple - Item Scale for Measuring Consumer Perception of Service Quality." Journal of Retailing. 64(1): 12-40.

Payne, A. and Holt, S. (2002). "Diagnosing Customer Value: Integrating the Value Process and Relationship Marketing". British Journal of Management. Vol. 12 Issue. 2

Peter, J. P. and Ryan, M. J. (1976). "An Investigation of Perceived Risk at the Brand Level." J Market Res 1976, 13, 184-8.

Qin, H., Prybutok, V.R., 2008. Determinants of customer-perceived service quality in fast-food Restaurant s and their relationship to customer satisfaction and behavioural intentions. Qual. Manag. J. 15(2), 35-50.

Ramseook-Munhurrun, P. (2012). "Perceived Service Quality in Restaurant". International Journal of Management and Marketing research. Vol.5, Issue 3. Pp 1-15.

Sasongko, A. and Puji, S. T. (2011) 50 Persen Produk Halal Impor Berasal dari China. Available at: https://www. republika.co.id/berita/dunia-islam/ fatwa/12/01/13/157117-50-persen-produk-halalimpor-berasal-dari-china

Schaninger, C.M. (1976), "Perceived risk and personality", Journal of Consumer Research, Vol. 3, September, pp. 95-100

Sekaran, F Vijayakumari, R Hariharan, K Zachariah, SE Joseph and RK Senthil Kumar. (2010). "Community reintegration of spinal cord-injured patients in rural south India". Department of Physical Medicine \& Rehabilitation, St Johns Medical College Hospital, Bangalore, Karnataka, India. Spinal Cord (2010) 48, 628-632

Shafie, S. and Othman, M.N. (2004), "Halal certification: international marketing issues and challenges", Track 13: International marketing and service.

Stone, R.N. and Winter, F.W. (1987), "Risk: is it still uncertainty times consequences?", in Belk, R.W. et al. (Eds), Proceedings of the American Marketing Association, Winter Educators Conference, Chicago, IL, pp. 261-5. 
Storbacka, K., Lehtinen, J.R., 2001. Customer Relationship Ship Management: Creating Competitive Advantage through Win-Win Relationship Strategies. McGraw- Hill Book Co, Singapore.

Susanto. I (2013). "Pengaruh Sertifikat Halal Terhadap Keputusan Pembelian Produk Makanan Texas Chicken.” http://irfansusanto85.blogspot.com/ 2013/09/skripsi-pengaruh-sertifikat- halal.html. Diakses pada tanggal, 16 September 2013

Talib, H.H.A., Ali, K.A.M. and Jamaludin, K.R. (2008), "Jamaludin Quality assurance in Halal food manufacturing in Malaysia: a preliminary study", Proceedings of International Conference on Mechanical and Manufacturing Engineering (ICME2008), 21-23 May 2008, Johor Bahru, Malaysia.

Taylor, Shirley and Peter A. Todd (1995), "Understanding Infor- mation Technology Usage: A Test of Competing Models," Information Systems Research, 6 (2), 144-76

Upadhyay, Y., S. Singh, and G. Thomas. (2007). "Do People Differ in their Preferences regarding Restaurant s? -- An Exploratory Study". Vision: The Journal of Business Perspective. Vol.11. Issue. 2, pp 7-22.

Viverita, Kusumastusti, R. D. and Rachmawati, R. (2017) 'Motives and Challenges of Small
Businesses for Halal Certification: The Case of Indonesia', World Journal of Social Sciences, 7(1), pp. 136-146.

Venkatesh, V. \& Davis, F. D. (2000). "A Theoretical Extension of the Technology Acceptance Model: Four Longitudinal Field Studies". February 2000 Management Science ,46(2):186-204

Wayne, V.M. (1999). "Consumer perceived risk: conceptualisations and models". Europian Journal Marketing. Vol. 33, issue. 1/2. pp.163-195.

Werner, P. 2004. Reasoned Action and Planned Behavior, in S.J. Peterson and T.S. Bredow (eds), Middle range Theories: Application to Nursing Research, Lippincott Williams and Wilkins, Philadelphia, pp. 125-147.

Yoo and Nayon (2014). Predicting consumer attitude and patronage intention toward fast fashion retailers: an illustration from U.S. college students. Retrieved from the University of Minnesota Digital Conservancy, http://hdl.handle.net/ 11299/169381.

Zakaria, Z. (2008), "Tapping into the world Halal market: some discussions on Malaysian laws and standards", Shariah Journal, Vol. 16, pp. 603616.

Zeithaml V.A. (1988). "Consumer Perceptions of Price, Quality, and Value”. Vol. 52. pp. 2-22. 